\title{
Feeding forages with reduced particle size in a total mixed ration improves feed intake, total-tract digestibility, and performance of organic dairy cows
}

\author{
Andreas Haselmann, ${ }^{1 *}$ Katharina Zehetgruber, ${ }^{1}$ Birgit Fuerst-Waltl, ${ }^{1}$ Werner Zollitsch, ${ }^{1}$ Wilhelm Knaus, ${ }^{1}$ \\ and Qendrim Zebeli ${ }^{2}$ \\ ${ }^{1}$ Department of Sustainable Agricultural Systems, Division of Livestock Sciences, BOKU—University of Natural Resources and Life Sciences, \\ 1180 Vienna, Austria \\ ${ }^{2}$ Institute of Animal Nutrition and Functional Plant Compounds, Department for Farm Animals and Veterinary Public Health, \\ University of Veterinary Medicine Vienna, 1210 Vienna, Austria
}

\section{ABSTRACT}

The optimal utilization of forages is crucial in cattle production, especially in organic dairy systems that encourage forage-based feeding with limited concentrate amounts. Reduction of the particle size of forages is known to improve feed intake and thus might be a viable option to help cows cope with less nutrient-dense feeds. The main aim of this study was to evaluate the effects of reducing forage particle size with a geometric mean of $52 \mathrm{~mm}$ (conventional particle size; CON) to 7 $\mathrm{mm}$ (reduced particle size; RED) in a high-forage diet ( $80 \%$ of dry matter) on dairy cows' sorting behavior, feed intake, chewing activity, and performance as well as on total-tract nutrient digestibility. Both diets (CON and RED) consisted of $43 \%$ grass hay, $37 \%$ clover-grass silage, and $20 \%$ concentrate and contained roughly $44 \%$ NDF, $15 \% \mathrm{CP}$, and $0.5 \%$ starch (dry matter basis). For CON, particle size was set by mixing all components for $20 \mathrm{~min}$ in a vertical feed mixer. The RED diet was treated the same, but before the mixer was filled, forages were chopped (theoretical length of cut $=0.5 \mathrm{~cm}$ ) and the hay was hammer-milled (sieve size $=2 \mathrm{~cm}$ ). Four primiparous and 16 multiparous midlactating dairy cows were assigned according to milk yield, body weight (BW), days in milk, and parity into 2 groups and fed 1 of the 2 diets for $34 \mathrm{~d}$. The first $13 \mathrm{~d}$ were used for diet adaption, followed by data collection of nutrient intake, chewing activity, sorting behavior, milk production, and nutrient digestibility for the last $21 \mathrm{~d}$ of the experiment. Seven days before the start of the experiment, data on BW, dry matter intake

Received December 20, 2018.

Accepted June 3, 2019.

*Corresponding author: andreas.haselmann@boku.ac.at
(DMI), chewing activity, sorting behavior, and milk production were collected for use as covariates. Results showed that the RED diet improved DMI $(+1.8 \mathrm{~kg} / \mathrm{d})$ and NDF intake $(+0.46 \mathrm{~kg} / \mathrm{d})$ but decreased intake of physically effective NDF $>8(-3.25 \mathrm{~kg} / \mathrm{d})$. The REDfed cows increased their intake of smaller particles $(<19$ $\mathrm{mm}$ ), whereas CON-fed cows sorted for long particles $(>19 \mathrm{~mm})$. The RED cows reduced eating and ruminating time per kilogram of DMI by 4.8 and 1.9 min, respectively, suggesting lower mastication efforts. In addition, the RED diet significantly increased apparent total-tract digestibility of nutrients. As a consequence, RED cows' energy-corrected milk yield was higher (27.0 vs. $29.3 \mathrm{~kg} / \mathrm{d}$ ) without affecting milk solids, cow BW, or feed efficiency. In conclusion, the data support a reduction of forage particle size in high-forage diets as a measure to improve energy intake, performance, and hence forage utilization under these feeding conditions. Key words: forage utilization, sorting behavior, chewing activity, barn-dried hay

\section{INTRODUCTION}

Forages such as grass silages and hay are sources of physically effective fiber in cattle diets and thus essential for cattle health and welfare. Unlike in the feeding of high-producing dairy cows, where dietary proportions of forages have been largely replaced by energy-dense concentrates, forages such as clover-grass silage and hay can account for up to $100 \%$ of daily rations, being the only source of energy and nutrients in grassland-based dairy production systems. The European Common Agricultural Policy encourages such systems, and numerous organic labels support farmers in feeding high-forage diets by paying a higher price for milk. In addition, from a food security point of view, forage-based livestock production improves the net human food supply (Wilkinson, 2011). 
However, a high inclusion rate of forages in dairy cattle diets is known to limit their DM and nutrient intake, with consequences for metabolic health and performance. Diets with a high fiber content and low nutrient and energy density, such as forage-based diets, require a substantially higher DMI to compensate for the lack of concentrates and fulfill the animals' high energy requirements. It has long been known that the bulkiness of feeds may cause an earlier termination of a meal due to the restricted distension capacity of the reticulo-rumen and hence restrict voluntary feed intake (Allen, 2000). Accordingly, the feeding of forages with a reduced particle size (RFPS) has been suggested earlier in the context of potentially enhancing DMI in conventional dairy cattle feeding (Tafaj et al., 2007; Nasrollahi et al., 2015). In the latter meta-analytical study, it was observed that feeding cows diets with an RFPS increased DMI and, to a lesser extent, performance, but it also lowered the digestibility of all nutrients. Such a response to RFPS is expected because in concentrate-rich diets, as typically fed in conventional dairy farming, feeding an RFPS leads to significantly fewer stimuli for rumination and salivation (Beauchemin et al., 2003), which, besides an increased passage rate (Zebeli et al., 2007), adversely affects rumen conditions and subsequently fiber degradation. However, in organic feeding systems with high forage proportions and minimal amounts of starchy concentrates, the effects of RFPS on the digestive variables mentioned above might be different. Other potential effects of RFPS in forage-based diets include changes in eating behavior of cows. Concordantly, as particle size decreases, the uniformity of diets increases, which was assumed to prevent cows from feed sorting (DeVries et al., 2008) and to increase diurnal fiber intake (Zebeli et al., 2012). Uniformity in particle size through chopped forages was also thought to facilitate the formation of the ruminal mat (Zebeli et al., 2012). As a proper ruminal mat might increase fiber degradation (Poppi et al., 2001; Tafaj et al., 2004; Zebeli et al., 2006), this aspect appears to be especially important when feeding high-forage diets. Most of the studies that tested the effects of RFPS in cows were conducted with diets rich in concentrates, or with starch-rich grains, as typically used in conventional dairy cattle production. Less focus has been placed on diets high in forages and low in concentrates and with concentrates that contain byproducts instead of starchy grains as energy sources, as typically used in organic dairy production systems. We hypothesized that feeding a high-forage diet $(80 \%$ DM basis) with an RFPS would improve DMI and milk performance of cows and that these effects would go along with adequate eating and ruminating behavior and an increased digestibility of nutrients.

\section{MATERIALS AND METHODS}

\section{Animals and Experimental Design}

The experiment was approved by the Institutional Ethics and Animal Welfare Committee of the University of Veterinary Medicine (Vetmeduni Vienna) in accordance with Good Scientific Practice guidelines and national legislation (protocol no. ETK-07/10/2017). The trial was carried out at the organic dairy farm of the Secondary School for Agriculture and Forestry HBLA Ursprung (Elixhausen, Austria; $570 \mathrm{~m}$ above sea level, $1,250 \mathrm{~mm}$ annual precipitation, $8.5^{\circ} \mathrm{C}$ average annual temperature) near the city of Salzburg, Austria, from the beginning of January 2018 until the beginning of March 2018. Cows were kept in a loosehousing system with cubicles in accordance with the European regulations on organic farming (European Commission, 2008). Individual feeding was guaranteed by transponder-regulated Calan gates (American Calan Inc., Northwood, NH).

We used 4 primiparous and 16 multiparous (second to ninth lactation) Holstein Friesian cows that were each assigned to 1 of the 2 treatment groups: 1 control group (forage particle size with a geometric mean of $52 \mathrm{~mm}$; conventional particle size, $\mathbf{C O N}$ ) and 1 experimental group (forage particle size reduced to a geometric mean of $7 \mathrm{~mm}$; RED). Assignments were based on average daily milk yield $(26.7 \pm 5.5 \mathrm{~kg})$ and $\mathrm{BW}(703 \pm 65 \mathrm{~kg})$ as well as DIM $(135 \pm 104)$ and number of lactations $(3.8 \pm 2.4)$ at the beginning of the trial. The experiment started with a covariate feeding period $(7 \mathrm{~d})$ followed by an experimental feeding period (34 d). During the covariate feeding period, all cows received the covariate TMR consisting of hay, clover-grass silage, corn silage, and a commercial concentrate premix including a mineral premix in a ratio (DM basis) of 26, 24, 25, and $25 \%$, respectively, meeting the requirements for energy and nutrients of cows weighing $700 \mathrm{~kg}$ and producing $30 \mathrm{~kg}$ milk according to GfE (2001). At the end of the covariate period, average ( \pm standard deviation) milk yield, DMI, BW, DIM, and parity were as follows for CON and RED, respectively: $29.9 \pm 4.92$ and $29.7 \pm$ $4.34 \mathrm{~kg}, 22.3 \pm 2.63$ and $21.8 \pm 2.13 \mathrm{~kg}, 691 \pm 64.6$ and $679 \pm 61.6 \mathrm{~kg}, 182 \pm 114$ and $169 \pm 89 \mathrm{~d}$, and $3.7 \pm 2.2$ and $3.8 \pm 2.7$. As a $t$-test for each of these parameters showed no significant differences $(P \geq 0.05)$ between groups, it was assumed that they were similar.

\section{Forages, Concentrates, TMR, and Feeding Regimen}

Forages used in this experiment were clover-grass silage and hay. For production of the clover-grass silage, wilted forage with an average DM content of 
$40 \%$ was cut (theoretical length of cut $=4 \mathrm{~cm}$ ) by a silage loading wagon (Europrofi Combiline, Pöttinger Landtechnik, Grieskirchen, Austria) and inoculated with Bon Silage Plus (Wilhelm Schaumann GmbH, An der Mühlenau, Germany) at a rate of $1 \times 10^{5} \mathrm{cfu} /$ $\mathrm{kg}$ of fresh material. The forage used for silage was obtained from the first and second cut in equal proportions from perennial clover-grass (65\% grass and $35 \%$ clover) and permanent grassland ( $\sim 50 \%$ grasses, $30 \%$ herbs, and $20 \%$ legumes). The grass for hay production was harvested at a DM content of $60 \%$ and barn dried using a dehumidifier and not chopped during the harvesting process. The forage used for hay was obtained only from permanent grassland from the first cut. The concentrate used for the TMR contained (DM basis) $40 \%$ field beans, $40 \%$ sunflower cake, $15 \%$ wheat bran, and $5 \%$ vitamin and mineral premix. The ingredients were obtained in ground and premixed form (including minerals and vitamins) from a commercial feed mill. Ingredients and chemical composition of the TMR are shown in Table 1. The TMR was prepared daily using a vertical feed mixer equipped with 1 auger and 4 blades (Smart 5, Siloking Mayer Maschinenbau GmbH, Tittmoning, Germany) at $32 \mathrm{rpm}$ with a mixing time of exactly $20 \mathrm{~min}$. Water was added to both TMR during mixing, ensuring an average DM content of $44 \%$ (Table 1). Before preparing the TMR with RFPS (i.e., the RED diet), both the hay and silage were chopped with a forage chopper (Blasisus 1034, Mengele Epple Maschinenbau, Guenzburg, Germany) adjusted to a theoretical length of cut of $0.5 \mathrm{~cm}$. The hay was then further shredded with a hammer mill (SMZ 30, Kirchner Agrar- und Kommunaltechnik GmbH, Anzenhof, Austria) equipped with 4 sets of hammers and a sieve with a mesh size of $20 \mathrm{~mm}$. Both TMR differed only in the particle size of the forages.

The TMR for the CON group had a conventional forage particle size with a geometric mean $\left(\mathbf{X}_{\mathrm{gm}}\right)$ of 52 $\mathrm{mm}$, and the TMR for the RED group had a forage particle size with an $\mathrm{X}_{\mathrm{gm}}$ of $7 \mathrm{~mm}$ (ASAE, 1992; Table 1). The TMR were offered twice a day after milking (0600 and $1630 \mathrm{~h}$ ), allowing 10\% for feed refusals. Feed was pushed up 7 times a day $(0700,0900,1100,1300$, 1730, 1930, and $2130 \mathrm{~h}$ ).

\section{Data Collection and Calculations}

Data were collected daily during the covariate period and, after $13 \mathrm{~d}$ of adaptation to the diet, during the last $21 \mathrm{~d}$ of the experimental period, unless stated otherwise. Dry matter intake was determined as the difference between the manually provided TMR and collected refusals. The DM content of the TMR and the
Table 1. Ingredients, chemical composition (\% DM basis unless stated otherwise; $\pm \mathrm{SD}$ ), and particle fractions ${ }^{1}$ of diets differing in forage particle size

\begin{tabular}{|c|c|c|}
\hline \multirow[b]{2}{*}{ Item $^{2}$} & \multicolumn{2}{|c|}{ Diet $^{3}$} \\
\hline & $\mathrm{CON}$ & RED \\
\hline \multicolumn{3}{|l|}{ Ingredient } \\
\hline Grass hay, first cut & 43.0 & 43.0 \\
\hline $\begin{array}{l}\text { Clover-grass silage, } \\
\text { first and second cut }\end{array}$ & 37.0 & 37.0 \\
\hline Concentrate $\operatorname{mix}^{4}$ & 20.0 & 20.0 \\
\hline \multicolumn{3}{|l|}{ Chemical composition ${ }^{5}$} \\
\hline DM (\% of fresh matter) & $43.6 \pm 1.6$ & $43.6 \pm 1.5$ \\
\hline $\mathrm{CP}$ & $15.4 \pm 0.3$ & $14.9 \pm 0.2$ \\
\hline $\mathrm{uCP}$ & $15.4 \pm 0.2$ & $15.3 \pm 0.1$ \\
\hline RNB ( $\mathrm{g} / \mathrm{kg}$ of $\mathrm{DM})$ & $-0.1 \pm 0.3$ & $-0.6 \pm 0.2$ \\
\hline Ether extract & $3.4 \pm 0.2$ & $3.4 \pm 0.1$ \\
\hline Ash & $9.0 \pm 0.4$ & $9.1 \pm 0.2$ \\
\hline Starch & $0.5 \pm 0.5$ & $0.2 \pm 0.4$ \\
\hline $\mathrm{NDF}$ & $44.4 \pm 1.2$ & $43.0 \pm 0.9$ \\
\hline $\mathrm{peNDF}_{>8}$ & $36.9 \pm 1.1$ & $21.2 \pm 0.5$ \\
\hline $\operatorname{peNDF}_{>1.18}$ & $42.2 \pm 1.2$ & $37.1 \pm 0.8$ \\
\hline $\mathrm{ADF}$ & $27.0 \pm 0.6$ & $26.3 \pm 0.8$ \\
\hline ADL & $3.5 \pm 0.3$ & $3.1 \pm 0.3$ \\
\hline $\mathrm{NE}_{\mathrm{L}}(\mathrm{MJ} / \mathrm{kg}$ of $\mathrm{DM})$ & $6.88 \pm 0.11$ & $6.95 \pm 0.08$ \\
\hline \multicolumn{3}{|l|}{$\begin{array}{l}\text { Particle fraction } \\
\text { (\% retained on screen) }\end{array}$} \\
\hline Long & $73.5 \pm 3.8$ & $23.0 \pm 3.9$ \\
\hline Medium & $9.6 \pm 1.6$ & $26.4 \pm 1.4$ \\
\hline Short & $11.9 \pm 1.9$ & $36.8 \pm 2.7$ \\
\hline Fine & $5.0 \pm 0.9$ & $13.8 \pm 1.4$ \\
\hline
\end{tabular}

${ }^{1}$ Particle fractions determined by Penn State Particle Separator with a 19-mm screen (long), 8-mm screen (medium), 1.18-mm screen (short), and a pan (fine) according to Kononoff et al. (2003a).

${ }^{2} \mathrm{uCP}=$ utilizable $\mathrm{CP}$ at the duodenum (GfE, 2001); RNB = ruminal $\mathrm{N}$ balance (GfE, 2001); peNDF $_{>8}, \mathrm{peNDF}_{>1.18}=$ physically effective $\mathrm{NDF}$, calculated as the cumulative DM proportion of particle fractions retained on 2 (19 and $8 \mathrm{~mm}$; peNDF $>8$ ) or 3 screens $(19,8,1.18 \mathrm{~mm}$; peNDF $>1.18$ ) multiplied by the NDF content of the TMR.

${ }^{3} \mathrm{CON}=$ conventional forage particle size, geometric mean $=52 \mathrm{~mm}$; $\mathrm{RED}=$ reduced forage particle size, geometric mean $=7 \mathrm{~mm}$.

${ }^{4}$ Concentrate mix contained (DM basis) $40 \%$ field beans, $40 \%$ sunflower cake, $15 \%$ wheat bran, and $5 \%$ vitamin and mineral premix.

${ }^{5}$ Means were based on 6 observations per treatment.

refusals was determined daily using a forced-air oven at $105^{\circ} \mathrm{C}$ for $24 \mathrm{~h}$. Particle size distribution of TMR on a DM basis (Table 1) was measured using the method described in Kononoff et al. (2003a) with a modified Penn State Particle Separator equipped with 3 screens $(19.0,8.0$, and $1.18 \mathrm{~mm})$ and a pan. The $\mathrm{X}_{\mathrm{gm}}$ length of particles was calculated in accordance with ASAE (1992). The size of particles retained on the top screen was estimated to be 125 and $50 \mathrm{~mm}$ for CON and RED, respectively, and the size of particles in the bottom pan was estimated to be $0.82 \mathrm{~mm}$ for both diets.

Feed selection of cows was determined once on 2 consecutive days and 2 times on 4 consecutive days during the covariate and the experimental period, respectively. To do so, particle size distribution was measured in refusals collected from the bunk before new feed was of- 
fered. Feed selection of each cow was expressed through the change in particle size distribution (as-fed basis) of the provided TMR in relation to the refusals. According to Leonardi and Armentano (2003), feed selection of a certain particle size fraction can be calculated as the percentage of the actual as-fed intake from the predicted as-fed intake, expressed by the selection index. The predicted intake of a specific particle fraction is calculated as the product of as-fed intake and as-fed proportion of this specific fraction in the TMR offered. Detailed information about the predicted and actual intake of different particle fractions, collected during the experimental period, is given in Appendix Table A1.

For chemical composition, samples of the provided TMR and the corresponding refusals were pooled for each group over 2 consecutive days, once during the covariate period and 6 times during the experimental period. Samples were immediately vacuum-packed and frozen at $-20^{\circ} \mathrm{C}$ until analysis in a commercial laboratory. Standard operating procedures of the laboratory were in accordance with VDLUFA (1993) with respect to procedures (parameters in parentheses) 4.1.2 (CP), 5.1.1 (ether extract), 8.1 (ash), 7.2.1 (starch), 6.5.1 (NDF), 6.5.2 (ADF), and 6.5.3 (ADL). Energy content of each sample was calculated according to GfE (2008) based on the results of pepsin-cellulase solubility of OM (VDLUFA, 1993) and proximate analysis. Content of physically effective fiber was calculated as the cumulative DM proportion of particle fractions retained on 2 (19 and $8 \mathrm{~mm}$; peNDF $>8$ ) or 3 screens $(19,8$, and 1.18 mm; $\left.\mathbf{p e N D F}_{>\mathbf{1 . 1 8}}\right)$ of the Penn State Particle Separator multiplied by the NDF content (DM basis) of the TMR (Kononoff et al., 2003a).

Chewing activity was measured using 10 RumiWatch noseband sensors (RumiWatch System, ITIN + HOCH $\mathrm{GmbH}$, Liestal, Switzerland). Five cows in each group wore these nosebands simultaneously for a set period of time, after which halters were switched to the remaining cows. Wearing periods were set from d 1 to 3 and d 6 to 8 in the covariate feeding period and from $\mathrm{d} 1$ to 7 and $\mathrm{d} 11$ to 16 in the experimental feeding period. The RumiWatch noseband sensor consists of a halter, a battery, an oil-filled tube, an accelerometer, and a data storage device. The change of pressure within the tube and the movement of the accelerometer are recorded at a frequency of $10 \mathrm{~Hz}$ to reflect the chewing activity of the cow (Kröger et al., 2016). After each recording period, data were transferred from the storage device via USB to the computer, and the RumiWatch converter V0.7.4.13 algorithm (RumiWatch System, ITIN $+\mathrm{HOCH} \mathrm{GmbH}$ ) was used to analyze chewing activity on a daily (24-h) basis.

Milk yield was registered automatically during milking $(0600$ and $1630 \mathrm{~h})$ in a $2 \times 3$ herringbone milking parlor. Milk samples from 2 consecutive milkings were taken, providing 2 and 4 observations per cow from the covariate and experimental periods, respectively. Samples were immediately conserved with Bronysolv (ANA.LI.TIK, Wien, Austria) and analyzed for fat, protein, lactose, and urea in a commercial laboratory using a Milkoscan (Foss Electric, Hillerød, Denmark). During both the covariate and experimental periods, cows were weighed immediately after 4 consecutive milkings over a period of $2 \mathrm{~d}$ on a weekly basis, resulting in 1 and 6 observations per cow from the covariate and experimental periods, respectively.

Backfat thickness (BFT) was measured with a portable ultrasound generator (Linear VET transrectal probe, SV3513 VET; Esaote SpA, Genoa, Italy) according to the procedure described in Schröder and Staufenbiel (2006). Changes in BFT and BW were calculated as the differences between the beginning and the end of the experimental period.

Apparent total-tract digestibility (ATTD) of nutrients for each cow was determined by using acid insoluble ash as an internal indicator. Fecal samples were collected within the last $5 \mathrm{~d}$ of the experimental period. Feces from each cow were taken from the rectum for 3 consecutive days every $8 \mathrm{~h}$, and approximately 200 $\mathrm{g}$ was immediately frozen at $-20^{\circ} \mathrm{C}$. Before chemical analysis, 9 samples from each cow were pooled, thoroughly mixed, dried with a freeze dryer (CoolSafe 100-9 Pro, LaboGene, Lillerød, Denmark), and then milled to $<500 \mu \mathrm{m}$ (ZM 200, Retsch GmbH, Haan, Germany). Acid insoluble ash was analyzed according to VDLUFA (1993).

\section{Statistical Analyses}

Data collected on a daily basis during the experimental period were analyzed using PROC MIXED of SAS 9.4 (SAS Institute Inc., Cary, NC). Data were checked for normal distribution and the presence of outliers. Data from the covariate period were averaged on a weekly basis. The statistical model included treatment (CON, RED), parity group $(1-3,>3)$, and day of the experiment as fixed effects, the corresponding value of the dependent variable from the covariate period as covariate, and cow nested within treatment as a random effect. Additionally, the measurements taken on the same animal but at different times (e.g., BW and milk yield) were considered as repeated measures in the model. Time dependency of data was modeled through an autoregressive covariance structure. Data for BFT, BW change, and ATTD were also analyzed with PROC MIXED, but day of the experiment was excluded and compound symmetry was used as a covariance structure in the model. The level of significance was considered 
to be $P<0.05$. The most suitable models were chosen according to Akaike information criterion (smaller was better).

\section{RESULTS}

\section{Diet Characteristics}

Data showed that both diets (CON and RED) had similar chemical composition (Table 1). First chopping the silage and hay and then further shredding the hay with a hammer mill reduced the proportions of long particles by 50.5 percentage units and increased those of medium, short, and fine particles by $16.8,24.9$, and 8.8 percentage units (DM basis), respectively. As a result, the distribution of particle fractions among the 4 sizes (long, medium, short, and fine) became more uniform with a total range of 23.0 percentage units, whereas short particles accounted for the greatest and fine particles for the smallest proportions. In contrast, for CON the range in distribution of particle fractions was 68.5 percentage units, indicating a more heterogenic TMR. As a result, the contents of $\mathrm{peNDF}_{>8}$ and $\mathrm{peNDF}_{>1.18}$ in RED decreased by 15.7 and 5.1 percentage units, respectively. The calculated geometric mean particle sizes in the CON and RED diets were approximately 52 and $7 \mathrm{~mm}$, respectively (ASAE, 1992).

\section{Sorting Behavior}

Rechopping forages before feeding led to an obvious change in feed sorting behavior (Table 2). The range of selection indices for all particle fractions within a group was higher when cows were fed the CON diet (10.7 percentage units) rather than the RED diet (5.3 percentage units). Notably, neither of the groups sorted against long particles, and CON-fed cows slightly increased $(P=0.119)$ selection toward this fraction. For medium and short particle fractions, we observed that CON cows sorted against these fractions to a greater extent than RED cows. Differences between groups accounted for 7.2 and 7.5 percentage units for medium and short fractions, respectively. The greatest discrepancy between groups was observed for the selective intake of fine particles. The RED cows sorted for this fraction, whereas CON cows avoided the intake of such particles.

\section{Chewing Behavior}

Although chopping forages reduced $(P=0.004)$ total chewing time (eating and ruminating time) by $44.6 \mathrm{~min} / \mathrm{d}$ (Table 3 ), the relative decrease was only $5.0 \%$. With regard to each kilogram of ingested DM and NDF, we observed a decrease $(P<0.001)$ in total
Table 2. Effects of a diet with reduced forage particle size on sorting of particle fractions in dairy cows on an as-fed basis ${ }^{1}$

\begin{tabular}{lrrrr}
\hline & \multicolumn{2}{c}{ Diet $^{3}$} & & \\
\cline { 2 - 3 } $\begin{array}{l}\text { Particle fractions } \\
\text { (as-fed basis) }\end{array}$ & CON & RED & \multirow{2}{*}{ SEM } & $P$-value \\
\hline Long & 101.5 & 100.4 & 0.45 & 0.119 \\
Medium & 90.8 & 98.0 & 1.09 & $<0.001$ \\
Short & 91.7 & 99.2 & 1.37 & 0.001 \\
Fine & 95.1 & 103.3 & 1.20 & $<0.001$ \\
\hline
\end{tabular}

${ }^{1}$ Selection index $=(\mathrm{n}$ intake $/ \mathrm{n}$ predicted intake $) \times 100$, where $\mathrm{n}=$ particle fraction (long, medium, short, fine). Values equal to 100 indicate no sorting, $<100$ indicate selective refusals (sorting against), and $>100$ indicate preferential consumption (sorting for; Leonardi and Armentano, 2003).

${ }^{2}$ Particle fractions determined by Penn State Particle Separator with a 19-mm screen (long), 8-mm screen (medium), 1.18-mm screen (short), and a pan (fine) according to Kononoff et al. (2003a).

${ }^{3} \mathrm{CON}=$ conventional forage particle size, geometric mean $=52 \mathrm{~mm}$; $\mathrm{RED}=$ reduced forage particle size, geometric mean $=7 \mathrm{~mm}$.

chewing time of 16 and $12 \%$, respectively. Conversely, total chewing time increased $(P<0.001)$ per kilogram of ingested peNDF $>8$ by $55.3 \%$ but decreased $(P=$ $0.037 ;-4.8 \%)$ per kilogram of peNDF $_{>1.18}$ in RED-fed cows.

Furthermore, total eating time was reduced $(P<$ 0.001 ) by $69.3 \mathrm{~min} / \mathrm{d}$ or $18.9 \%$ in RED-fed cows compared with CON-fed cows. Eating time per kilogram of DMI and NDF ( $\mathrm{min} / \mathrm{kg}$ ) was reduced by $4.8 \mathrm{~min}(27 \%)$

Table 3. Chewing behavior of dairy cows fed a diet with a reduced forage particle size

\begin{tabular}{|c|c|c|c|c|}
\hline \multirow[b]{2}{*}{ Item $^{1}$} & \multicolumn{2}{|c|}{ Diet $^{2}$} & \multirow[b]{2}{*}{ SEM } & \multirow[b]{2}{*}{$P$-value } \\
\hline & $\mathrm{CON}$ & RED & & \\
\hline \multicolumn{5}{|l|}{ Total chewing time } \\
\hline $\mathrm{min} / \mathrm{kg}$ of $\mathrm{DM}$ & 43.4 & 36.6 & 0.63 & $<0.001$ \\
\hline $\min / \mathrm{kg}$ of $\mathrm{NDF}$ & 97.6 & 86.2 & 1.43 & $<0.001$ \\
\hline $\mathrm{min} / \mathrm{kg}$ of $\mathrm{peNDF}_{>8}$ & 114.0 & 177.0 & 2.48 & $<0.001$ \\
\hline $\mathrm{min} / \mathrm{kg}$ of $\mathrm{peNDF}_{>1.18}$ & 101.9 & 97.0 & 1.50 & 0.037 \\
\hline \multicolumn{5}{|l|}{ Eating time } \\
\hline $\min / \mathrm{d}$ & 365.9 & 296.6 & 6.93 & $<0.001$ \\
\hline $\min / \mathrm{kg}$ of DM & 17.6 & 12.8 & 0.40 & $<0.001$ \\
\hline $\mathrm{min} / \mathrm{kg}$ of $\mathrm{NDF}$ & 39.6 & 30.0 & 0.92 & $<0.001$ \\
\hline $\mathrm{min} / \mathrm{kg}$ of $\mathrm{peNDF}_{>8}$ & 46.5 & 61.7 & 1.46 & $<0.001$ \\
\hline $\min / \mathrm{kg}$ of $\mathrm{peNDF}_{>1.18}$ & 41.4 & 33.8 & 0.96 & $<0.001$ \\
\hline \multicolumn{5}{|l|}{ Ruminating time } \\
\hline $\min / \mathrm{d}$ & 533.3 & 557.9 & 8.74 & 0.069 \\
\hline $\min / \mathrm{kg}$ of DM & 25.8 & 23.9 & 0.43 & 0.008 \\
\hline $\min / \mathrm{kg}$ of $\mathrm{NDF}$ & 58.0 & 56.2 & 0.94 & 0.190 \\
\hline $\mathrm{min} / \mathrm{kg}$ of $\mathrm{peNDF}_{>8}$ & 67.6 & 115.4 & 1.58 & $<0.001$ \\
\hline $\mathrm{min} / \mathrm{kg}$ of $\mathrm{peNDF}>1.18$ & 60.6 & 63.2 & 1.00 & 0.085 \\
\hline
\end{tabular}

${ }^{1}$ peNDF $_{>8}$, peNDF $_{>1.18}=$ physically effective NDF, calculated as the cumulative DM proportion of particle fractions retained on 2 (19 and 8 $\left.\mathrm{mm} ; \mathrm{peNDF}_{>8}\right)$ or 3 screens $\left(19,8,1.18 \mathrm{~mm} ; \mathrm{peNDF}_{>1.18}\right)$ of the Penn State Particle Separator multiplied by the NDF content (DM basis) of the TMR (Kononoff et al., 2003a).

${ }^{2} \mathrm{CON}=$ conventional forage particle size, geometric mean $=52 \mathrm{~mm}$; $\mathrm{RED}=$ reduced forage particle size, geometric mean $=7 \mathrm{~mm}$. 
and $9.6 \min (24 \%)$, respectively, when feeding the RED diet. Additionally, eating time per kilogram of ingested peNDF $_{>8}$ was prolonged $(P<0.001)$ by $32.7 \%$, whereas time per kilogram of ingested $\mathrm{peNDF}_{>1.18}$ was reduced $(P<0.001)$ by $18.4 \%$.

Conversely, as eating time was reduced in the RED feeding group, ruminating time was slightly extended by $24.6 \mathrm{~min} / \mathrm{d}$ or $4.6 \%(P=0.069)$ compared with the CON group. However, rumination time per kilogram of ingested DM was reduced $(P=0.008)$ by $1.9 \mathrm{~min}$ (7.4\%) in RED cows compared with CON cows. Accordingly, rumination time per kilogram of NDF was also reduced by $1.8 \mathrm{~min}(3.1 \%)$, although this difference was not significant $(P=0.190)$. The RED-fed cows spent a longer time ruminating each kilogram of physically effective fiber than CON-fed cows, with increases of $70.7 \%(P<0.001)$ and $4.3 \%(P=0.085)$ for $\mathrm{peNDF}_{>8}$ and $\operatorname{peNDF}_{>1.18}$, respectively.

\section{Nutrient Intake, Milk Production, and Body Condition}

The RED treatment increased DMI by $1.8 \mathrm{~kg} / \mathrm{d}$ $(P<0.001 ;$ Table 4$)$. When expressing this increase as the percentage of $\mathrm{BW}(P=0.003)$, it accounted for 0.23 percentage units. As DMI increased in RED, intake of NDF and ADF was also higher, accounting for $4.9 \%$ and $5.7 \%$, respectively, but ADL intake was slightly reduced $(P=0.084)$ by $4.2 \%$ in this group. On the other hand, chopped forages reduced the intake of peNDF $_{>8}$ by $40.5 \%$ but not that of $\operatorname{peNDF}_{>1.18}(P=$ 0.111). When relating these intake parameters to BW of cows, we observed similar effects. Daily intake of ether extract increased by $8.5 \%(P<0.001)$ when the RED diet was fed, whereas the intake of starch did not change $(P=0.554)$. Concordantly, with the higher nutrient intake in the RED feeding group, estimated energy supply improved $(P<0.001)$ by $10 \%$. Consequently, the provision of utilizable $\mathrm{CP}$ at the duodenum (GfE, 2001) also improved by $7.7 \%$, although the supply of CP was elevated by only $5.3 \%$. The increase in energy supply resulted in a positive effect $(P=0.004)$ on the energy balance of cows but not on utilizable CP balance $(P=0.217$; Table 5$)$. Because of the elevated nutrient and energy intake, ECM production increased by $8.5 \%(P<0.001)$. This was the result of an increase of milk yield (least squares means of 26.0 and $28.0 \mathrm{~kg}$, respectively; data not shown) as milk fat, protein, and lactose remained at the same level. However, milk urea content was reduced $(P=0.006)$ by $26.2 \%$ in the RED feeding group. Furthermore, RED cows showed a higher weight gain $(0.81 \mathrm{~kg} / \mathrm{d})$ than CON cows $(0.34 \mathrm{~kg} / \mathrm{d} ; P$ $=0.005)$. However, BFT change over the course of the trial as well as BW of cows at the end of the trial did not significantly differ between groups. Feed efficiency and efficiency of $\mathrm{N}$ use were also not influenced by the diet.

ATTD

Feeding cows a diet with RFPS enhanced the ATTD of all nutrients (Table 6). The greatest increases were observed for ether extract followed by CP, DM, OM, $\mathrm{NDF}$, and ADF, accounting for 13.4, 7.7, 5.4, 4.8, 3.3, and 2.5 percentage units, respectively. No differences $(P=0.339)$ between the feeding groups were observed for DM content of feces. For $\mathrm{pH}$ of feces, however, a slight decrease $(P=0.058)$ was found when cows were fed the RED diet.

\section{DISCUSSION}

This study was designed to evaluate whether a reduction in the conventional particle size typically fed on grassland-based farms in Alpine regions to a theoretical length of cut of $\leq 0.5 \mathrm{~cm}$ would affect forage utilization on organic dairy farms. Indeed, we found a significant improvement in forage utilization by reducing the particle size of clover-grass silage and hay fed to dairy cows. More specifically, we observed that feeding the RED diet improved DMI and nutrient digestibility,

Table 4. Effects of a diet with reduced forage particle size on daily intake of nutrients and energy of dairy cows

\begin{tabular}{lrrrr}
\hline & \multicolumn{2}{c}{ Diet $^{2}$} & & \\
\cline { 2 - 3 } Item $^{1}$ & CON & RED & SEM & $P$-value \\
\hline Intake $(\mathrm{kg} / \mathrm{d})$ & 21.00 & 22.80 & 0.231 & $<0.001$ \\
DM & 9.31 & 9.77 & 0.101 & 0.008 \\
NDF & 8.03 & 4.78 & 0.067 & $<0.001$ \\
peNDF & 8.92 & 8.69 & 0.091 & 0.111 \\
peNDF & 5.18 & 5.97 & 0.068 & 0.005 \\
ADF & 0.72 & 0.69 & 0.011 & 0.084 \\
ADL & 3.22 & 3.39 & 0.034 & 0.006 \\
CP & 3.24 & 3.49 & 0.034 & $<0.001$ \\
uCP & 0.12 & 0.09 & 0.033 & 0.554 \\
Starch & 0.71 & 0.77 & 0.008 & $<0.001$ \\
Ether extract & 145 & 159 & 1.6 & $<0.001$ \\
Energy (MJ of NE & & & & \\
Intake $(\%$ of BW) & 3.03 & 3.26 & 0.047 & 0.003 \\
DMI & 1.34 & 1.40 & 0.022 & 0.067 \\
NDF & 1.16 & 0.68 & 0.013 & $<0.001$ \\
peNDF & 1.28 & 1.24 & 0.020 & 0.173 \\
peNDF & & & & \\
\hline
\end{tabular}

${ }^{1} \operatorname{peNDF}_{>8}$, peNDF $_{>1.18}=$ physically effective fiber, cumulative DM proportion of particle fractions retained on 2 (19 and $8 \mathrm{~mm}$; peNDF $>8$ ) or 3 screens $\left(19,8\right.$, and $1.18 \mathrm{~mm}$; $\left.\operatorname{peNDF}_{>1.18}\right)$ of the Penn State Particle Separator multiplied by the NDF content (DM basis) of the TMR (Kononoff et al., 2003a); uCP = utilizable CP at the duodenum (GfE, 2001).

${ }^{2} \mathrm{CON}=$ conventional forage particle size, geometric mean $=52 \mathrm{~mm}$; $\mathrm{RED}=$ reduced forage particle size, geometric mean $=7 \mathrm{~mm}$. 
Table 5. Effects of a diet with reduced forage particle size on milk production, body condition change, nutrient balance, and efficiency parameters of dairy cows

\begin{tabular}{|c|c|c|c|c|}
\hline \multirow[b]{2}{*}{ Item } & \multicolumn{2}{|c|}{$\operatorname{Diet}^{1}$} & \multirow[b]{2}{*}{ SEM } & \multirow[b]{2}{*}{$P$-value } \\
\hline & $\mathrm{CON}$ & RED & & \\
\hline \multicolumn{5}{|l|}{ Milk parameter } \\
\hline ECM $(\mathrm{kg} / \mathrm{d})$ & 27.0 & 29.3 & 0.36 & $<0.001$ \\
\hline Fat $(\%)$ & 4.37 & 4.40 & 0.124 & 0.839 \\
\hline Protein $(\%)$ & 3.40 & 3.40 & 0.034 & 0.851 \\
\hline Lactose $(\%)$ & 4.74 & 4.76 & 0.022 & 0.444 \\
\hline Urea $(\mathrm{mg} / 100 \mathrm{~mL})$ & 14.5 & 10.7 & 0.860 & 0.006 \\
\hline $\mathrm{SCC}\left(\times 10^{3} / \mathrm{mL}\right)$ & 138 & 149 & 37.0 & 0.848 \\
\hline BW at end of trial $(\mathrm{kg})$ & 694 & 713 & 20.0 & 0.526 \\
\hline BW change $(\mathrm{kg} / \mathrm{d})$ & 0.34 & 0.81 & 0.108 & 0.005 \\
\hline Backfat thickness change (mm) & -1 & 0 & 0.9 & 0.381 \\
\hline $\mathrm{NE}_{\mathrm{L}}$ balance $^{2}(\%)$ & 110 & 115 & 1.1 & 0.004 \\
\hline uCP balance ${ }^{2,3}(\%)$ & 124 & 126 & 0.9 & 0.217 \\
\hline Feed conversion efficiency ( $\mathrm{kg}$ of ECM $/ \mathrm{kg}$ of DMI) & 1.31 & 1.29 & 0.015 & 0.366 \\
\hline $\mathrm{N}$ efficiency (milk $\mathrm{N}$ in $\%$ of $\mathrm{N}$ intake) & 27.5 & 27.9 & 0.33 & 0.457 \\
\hline
\end{tabular}

${ }^{1} \mathrm{CON}=$ conventional forage particle size, geometric mean $=52 \mathrm{~mm}$; RED $=$ reduced forage particle size, geometric mean $=7 \mathrm{~mm}$.

${ }^{2}$ Calculated according to methods of GfE (2001): (intake/requirements) $\times 100$.

${ }^{3}$ Utilizable CP at the duodenum (GfE, 2001).

tended to prolong rumination time, and had a positive, if unexpected, influence on cows' feed sorting behavior.

In light of the importance of high DMI when feeding high-forage diets, the intake of the CON group was high according to results observed under similar feeding conditions (Ertl et al., 2016). Based on this, the increase of $1.8 \mathrm{~kg} / \mathrm{d}$ through feeding a TMR containing rechopped forages is remarkable. The elevation in DMI turns out to be substantial when compared with the meta-analytical results of Nasrollahi et al. (2015), who reported an average increase of $0.5 \mathrm{~kg} / \mathrm{d}$. More specifically, when relating feed intake to $100 \mathrm{~kg}$ of $\mathrm{BW}$, the increase accounted for $0.23 \mathrm{~kg} / \mathrm{d}$. This finding suggests that rechopped forages probably allow cows to make

Table 6. Effects of a diet with reduced forage particle size on apparent total-tract digestibility (ATTD) and DM content and $\mathrm{pH}$ of feces of dairy cows

\begin{tabular}{lcccr}
\hline & \multicolumn{2}{c}{ Diet $^{1}$} & & \\
\cline { 2 - 3 } Item & CON & RED & SEM & $P$-value \\
\hline ATTD (\%) & 69.4 & 74.8 & 0.48 & $<0.001$ \\
DM & 71.6 & 76.4 & 0.50 & $<0.001$ \\
OM & 63.2 & 70.9 & 0.50 & $<0.001$ \\
CP & 50.7 & 64.1 & 1.14 & $<0.001$ \\
Ether extract & 70.4 & 73.7 & 0.83 & 0.012 \\
NDF & 68.1 & 70.6 & 0.75 & 0.026 \\
ADF & 12.2 & 11.6 & 0.47 & 0.339 \\
DM of feces & & & & \\
(\% of fresh matter) & 7.25 & 7.17 & 0.03 & 0.058 \\
pH of feces &
\end{tabular}

${ }^{1} \mathrm{CON}=$ conventional forage particle size, geometric mean $=52 \mathrm{~mm}$; $\mathrm{RED}=$ reduced forage particle size, geometric mean $=7 \mathrm{~mm}$. better use of rumen capacity by reaching physical satiety at a later stage and achieving greater ruminal fill than when fed the CON diet (Allen, 2000).

The higher feed intake in RED cows can also be attributed to the lower total chewing time. Mertens (1997) postulated that chewing capacity can limit feed intake. According to Susenbeth et al. (1998, 2004), energy expenditure for eating and ruminating accounts for roughly 20 and $9 \mathrm{~J} / \mathrm{min}$ per kilogram of BW, respectively. Data from the current study showed a marked decrease in total eating time $(69.3 \mathrm{~min} / \mathrm{d})$, whereas ruminating time tended to increase $(24.6 \mathrm{~min} / \mathrm{d})$. Calculating the latter values for a $700-\mathrm{kg}$ cow, the total decrease in energy costs was $0.82 \mathrm{MJ}$ of $\mathrm{ME} / \mathrm{d}$. Although this indicates that the RED diet enabled cows to save energy during mastication (i.e., lower mastication efforts), the reduction appeared to be negligible with regard to the total energy requirements of roughly $220 \mathrm{MJ}$ of $\mathrm{ME} / \mathrm{d}$ of a cow producing $30 \mathrm{~kg}$ of milk/d (GfE, 2001).

The increased feed intake of RED-fed cows was also caused by a higher digestibility of fiber (Oba and Allen, 1999). Several factors may have contributed to fiber degradation in the RED diet. First, contact surface for rumen microbes was enlarged by the chopping procedure. This also resulted in an easier and faster availability of nutrients for microbiota, which in turn may have increased microbial activity (Thomas and Russell, 2004). Furthermore, the increased digestibility of nutrients, together with the lower chewing time per kilogram of DMI, suggests that the contribution of microbes to particle breakdown must have been greater (Beauchemin, 1991). Second, the RED diet showed a 
more uniform particle distribution, which in turn facilitates the formation of the ruminal mat (Zebeli et al., 2012). Ruminal mat formation is also improved by the intake of forage NDF, which was observed in the RED group (Zebeli et al., 2012). A proper ruminal mat enables better entrapment of potentially escapable particles, which in turn increases the time allowance for fiber degradation in the rumen (Poppi et al., 2001; Tafaj et al., 2004; Zebeli et al., 2006).

Feed sorting behavior of cows was less pronounced when feeding a TMR containing chopped forages. This is in agreement with previous studies (Leonardi and Armentano, 2003; Zebeli et al., 2008). However, values in the CON group appeared to be very different compared with previous publications. In this regard, it should be pointed out that the selection index describes only relative changes between the actual and the predicted intake of a particular fraction. Thus, it is more likely that selection indices deviate strongly from 100 when the total predicted intake of a particular fraction is rather small (e.g., medium, short, and fine fractions of the CON diet; Appendix Table A1). In addition, it should be considered that a greater index (e.g., the index of the fine fraction in RED and the index of the long fraction in $\mathrm{CON}$ ) did not necessarily mean a greater intake of a particular fraction.

The CON-fed cows ingested a higher amount of long particles and even preferred this fraction (i.e., selection index >100), which contradicts findings in studies using concentrate-based diets (Kononoff et al., 2003b; Leonardi and Armentano, 2003). Intuitively, one could speculate that longer particles were more easily accessible than smaller particles for CON-fed cows. DeVries et al. (2007) showed that a higher forage inclusion level (50.7 vs. $62.3 \%$, DM basis) increased cows' preference for long particles. Nasrollahi et al. (2014) reported that feeding long lucerne hay increased cows' intake of coarser particles $(>8 \mathrm{~mm})$. As we used substantially higher proportions of forages in our diets and a longer forage particle size, it is possible that this amplified the effects. Because our cows had little experience with TMR due to extended grazing periods, it could also be speculated that the animals' sorting behavior may have been affected by this factor (Miller-Cushon and DeVries, 2017). Consequently, the greater intake of long particles could have resulted in a greater ruminal distension and a reduced passage rate, which in turn might have impaired DMI (Kammes and Allen, 2012).

On the other hand, RED cows sorted for smaller particles $(<19 \mathrm{~mm})$, suggesting a greater intake of this fraction compared with CON cows. Due to chopping, the RED diet contained higher proportions of hay and silage in the medium and short fraction than the CON diet, whereby the fine particle pool of the RED diet was enriched solely by hammer-milled hay. It is possible that forages of good quality were more attractive for cows than the concentrate because of the inclusion of less palatable field beans in the latter. Particularly, Kleefisch et al. (2018) emphasized that barn-dried hay of good quality is highly attractive for cows. Given this observation, it can be speculated that chopping reduced cows' perception of unpleasant flavors by achieving a better distribution of palatable components in different particle pools. As a result, the difference between the TMR offered and that ingested might have been lessened in RED-fed cows (Leonardi and Armentano, 2003). This might have also improved the dietary nutrient balance for rumen microbiota, probably mirroring the improvements in nutrient digestibility of the RED diet (Thomas and Russell, 2004). For practical applications, it can be suggested that a more uniform particle size of forages enhances ingestion of the less palatable legumes that are often used in organic dairy rations.

As expected, the animals' chewing activity was reduced by feeding the RED diet; however, the absolute level still ranged around the maximum reported by White et al. (2017) in their review of 60 publications. More specifically, the decrease in total chewing time was probably a consequence of substantially lower eating times, as rumination tended to increase in the RED group. This is supported by the theory that a less intensive comminution of feed particles during eating is compensated for by prolonged mastication during rumination (Nasrollahi et al., 2016; Beauchemin, 2018). However, our findings also suggest that the physical properties of the RED diet still fulfill the requirements for cows despite the remarkably reduced intake of peNDF in the RED group. Therefore, it is reasonable to assume that the greater uniformity of particle size in the RED diet improved daily fiber intake, which in turn stimulated rumination (Zebeli et al., 2012). Beauchemin (2018) also emphasized the importance of forage NDF intake for rumination.

Due to the elevated DMI, an increase in milk production by approximately $3.6 \mathrm{~kg} / \mathrm{d}$ could be expected (GfE, 2001). Although we observed an increase of only $2.3 \mathrm{~kg} / \mathrm{d}$, which represents about $64 \%$ of the additional energy supply, this still seems remarkable. Analyzing milk performance and DMI data of 46 publications dealing with RFPS, Nasrollahi et al. (2015) suggested that only half of the additional feed energy was used for milk production and that the other half was probably used for body tissue accretion. The comparably low increase in milk production was ascribed to the relatively short experimental time in which cows were exposed to RFPS. It was also postulated that the shortterm increase in intravenous glucose supply may have enlarged body reserves (Al-Trad et al., 2009) instead 
of increasing milk production. Thus, the relatively long experimental period of our feeding trial may have enabled cows to better respond to the elevated energy supply with increased milk production. A potential reason for this different response might be the low concentration of starch and the resulting higher availability of lipogenic nutrients (Boerman et al., 2015) in this study compared with others. However, we also speculate that the availability of glucogenic and proteinic nutrients might have increased for RED cows due to the greater DMI as well as the ingestion of fine particles. This together with improved utilization of fiber (increased lipogenic nutrients) could have increased the total amounts of the precursors for milk synthesis in RED-fed cows (van Knegsel et al., 2007). Contrarily, precursors derived from body reserves were not likely to be responsible for this increase because cows were in a positive energy balance, whereby the RED cows showed an even higher daily gain compared with CON cows. Furthermore, BFT remained constant and estimated energy balance was positively modulated by the RED diet (GfE, 2001).

It is also possible that a higher increase of milk production in RED cows was limited by the available $\mathrm{N}$ supply for rumen microbiota (Hof et al., 1997), which was reflected in a low milk urea content of this group. The greater availability of dietary energy for microbiota in RED-fed cows due to increased nutrient digestibility most likely enhanced microbial activity, but at the same time the suboptimal $\mathrm{N}$ provision might have restricted ruminal fermentation (Broderick, 2003). However, a higher passage rate of feed ingesta in RED-fed cows may have also decreased the amount of $\mathrm{N}$ available for microbiota (Dufreneix et al., 2019).

\section{CONCLUSIONS}

Reducing the particle size of good-quality forages included in a high-forage TMR improved dairy cows' energy supply, suggesting a better forage utilization. Feed intake was improved by the decreased mastication efforts required and probably by a better use of rumen capacity. Although lower times spent chewing each kilogram of ingested feed suggest a lower mechanical particle breakdown, the greater initial contact area might have improved microbial colonization and thus ATTD of nutrients. A reduction in selective feed consumption might have also made a more balanced nutrient spectrum available to microorganisms. Milk production was affected by the improved energy supply, and the relatively long observation period may have contributed to this effect. Because diets were low in starch, the higher total fiber intake per se was more important to induce rumination than the intake of physically effective fiber.
To introduce these findings into practice, it would be necessary to optimize the forage chopping procedure as well as test diets with other forage particle sizes.

\section{ACKNOWLEDGMENTS}

The authors are grateful to the Austrian Federal Ministry for Sustainability and Tourism, the Provincial Government of Salzburg (Austria), Raiffeisenverband Salzburg, and the "Ja! Natürlich!" brand of the REWE group (Wiener Neudorf, Austria) for funding this experiment. In addition, we are grateful to the secondary school for agriculture and forestry HBLA Ursprung (Elixhausen, Austria) for housing the experiment; to the farm staff, especially Franz Griessner, for helping with the experimental work; and to Gruber Maschinen GmbH (Gaspoltshofen, Austria) and the Karl J. Mayer company (Krenglbach, Austria) for technical advice on chopping feed. We also thank Anita Dockner (Institute of Animal Nutrition and Functional Plant Compounds at the University of Veterinary Medicine Vienna, Austria) for performing chemical analyses and Kathleen Knaus (University of Vienna, Austria) for editing assistance.

\section{REFERENCES}

Al-Trad, B., K. Reisberg, T. Wittek, G. B. Penner, A. Alkaassem, G. Gäbel, M. Fürll, and J. R. Aschenbach. 2009. Increasing intravenous infusions of glucose improve body condition but not lactation performance in midlactation dairy cows. J. Dairy Sci. 92:56455658. https://doi.org/10.3168/jds.2009-2264.

Allen, M. S. 2000. Effects of diet on short-term regulation of feed intake by lactating dairy cattle. J. Dairy Sci. 83:1598-1624. https:// doi.org/10.3168/jds.S0022-0302(00)75030-2.

ASAE (American Society of Agricultural Engineers). 1992. ANSI/ ASAE S424.1 MAR1992 (R2017). Method of determining and expressing particle size of chopped forage materials by screening. American Society of Agricultural Engineers, St. Joseph, MI.

Beauchemin, K. A. 1991. Ingestion and mastication of feed by dairy cattle. Vet. Clin. North Am. Food Anim. Pract. https://doi.org/ 10.1016/S0749-0720(15)30794-5.

Beauchemin, K. A. 2018. Invited review: Current perspectives on eating and rumination activity in dairy cows. J. Dairy Sci. 101:47624784. https://doi.org/10.3168/jds.2017-13706.

Beauchemin, K. A., W. Z. Yang, and L. M. Rode. 2003. Effects of particle size of alfalfa-based dairy cow diets on chewing activity, ruminal fermentation, and milk production. J. Dairy Sci. 86:630-643. https://doi.org/10.3168/jds.S0022-0302(03)73641-8.

Boerman, J. P., S. B. Potts, M. J. VandeHaar, and A. L. Lock. 2015. Effects of partly replacing dietary starch with fiber and fat on milk production and energy partitioning. J. Dairy Sci. 98:7264-7276. https://doi.org/10.3168/jds.2015-9467.

Broderick, G. A. 2003. Effects of varying dietary protein and energy levels on the production of lactating dairy cows. J. Dairy Sci. 86:1370-1381. https://doi.org/10.3168/jds.S0022-0302(03)73721 $-7$.

DeVries, T. J., K. A. Beauchemin, and M. A. G. von Keyserlingk. 2007. Dietary forage concentration affects the feed sorting behavior of lactating dairy cows. J. Dairy Sci. 90:5572-5579. https://doi .org/10.3168/jds.2007-0370.

DeVries, T. J., F. Dohme, and K. A. Beauchemin. 2008. Repeated ruminal acidosis challenges in lactating dairy cows at high and low 
risk for developing acidosis: Feed sorting. J. Dairy Sci. 91:3958 3967. https://doi.org/10.3168/jds.2008-1347.

Dufreneix, F., P. Faverdin, and J. L. Peyraud. 2019. Influence of particle size and density on mean retention time in the rumen of dairy cows. J. Dairy Sci. 102:3010-3022. https://doi.org/10.3168/ jds.2018-15926.

Ertl, P., Q. Zebeli, W. Zollitsch, and W. Knaus. 2016. Feeding of wheat bran and sugar beet pulp as sole supplements in high-forage diets emphasizes the potential of dairy cattle for human food supply. J. Dairy Sci. 99:1228-1236. https://doi.org/10.3168/jds.2015 $-10285$.

European Commission. 2008. Commission Regulation (EC) No. $889 / 2008$ of 5 September 2008.

GfE. 2001. Recommendations for the Supply of Energy and Nutrients to Dairy Cows and Heifers. Committee for Requirement Standards of the Society of Nutrition Physiology. German Society of Nutrition Physiology, ed. DLG Verlag, Frankfurt am Main, Germany.

GfE. 2008. Prediction of metabolizeable energy of compound feeds for ruminants. Proc. Soc. Nutr. Physiol. 17:199-204.

Hof, G., M. D. Vervoorn, P. J. Lenaers, and S. Tamminga. 1997. Milk urea nitrogen as a tool to monitor the protein nutrition of dairy cows. J. Dairy Sci. 80:3333-3340. https://doi.org/10.3168/jds .S0022-0302(97)76309-4.

Kammes, K. L., and M. S. Allen. 2012. Nutrient demand interacts with grass particle length to affect digestion responses and chewing activity in dairy cows. J. Dairy Sci. 95:807-823. https://doi .org/10.3168/jds.2011-4588.

Kleefisch, M. T., Q. Zebeli, E. Humer, L. Gruber, and F. Klevenhusen. 2018. Effects of feeding high-quality hay with graded amounts of concentrate on feed intake, performance and blood metabolites of cows in early lactation. Arch. Anim. Nutr. 72:290-307. https://doi .org/10.1080/1745039X.2018.1474004.

Kononoff, P. J., A. J. Heinrichs, and D. R. Buckmaster. 2003a. Modification of the Penn State Forage and Total Mixed Ration Particle Separator and the effects of moisture content on its measurements. J. Dairy Sci. 86:1858-1863. https://doi.org/10.3168/jds.S0022 $-0302(03) 73773-4$

Kononoff, P. J., A. J. Heinrichs, and H. A. Lehman. 2003b. The effect of corn silage particle size on eating behavior, chewing activities, and rumen fermentation in lactating dairy cows. J. Dairy Sci. 86:3343-3353. https://doi.org/10.3168/jds.S0022-0302(03)73937 $-\mathrm{X}$.

Kröger, I., E. Humer, V. Neubauer, N. Kraft, P. Ertl, and Q. Zebeli. 2016. Validation of a noseband sensor system for monitoring ruminating activity in cows under different feeding regimens. Livest. Sci. 193:118-122. https://doi.org/10.1016/j.livsci.2016.10.007.

Leonardi, C., and L. E. Armentano. 2003. Effect of quantity, quality, and length of alfalfa hay on selective consumption by dairy cows. J. Dairy Sci. 86:557-564. https://doi.org/10.3168/jds.S0022 -0302(03)73634-0.

Mertens, D. R. 1997. Creating a system for meeting the fiber requirements of dairy cows. J. Dairy Sci. 80:1463-1481. https://doi.org/ 10.3168/jds.S0022-0302(97)76075-2.

Miller-Cushon, E. K., and T. J. DeVries. 2017. Feed sorting in dairy cattle: Causes, consequences, and management. J. Dairy Sci. 100:4172-4183. https://doi.org/10.3168/jds.2016-11983.

Nasrollahi, S. M., G. R. Ghorbani, M. Khorvash, and W. Z. Yang. 2014. Effects of grain source and marginal change in lucerne hay particle size on feed sorting, eating behaviour, chewing activity, and milk production in mid-lactation Holstein dairy cows. J. Anim. Physiol. Anim. Nutr. (Berl.) 98:1110-1116. https://doi.org/ 10.1111/jpn.12185.

Nasrollahi, S. M., M. Imani, and Q. Zebeli. 2015. A meta-analysis and meta-regression of the effect of forage particle size, level, source, and preservation method on feed intake, nutrient digestibility, and performance in dairy cows. J. Dairy Sci. 98:8926-8939. https://doi .org/10.3168/jds.2015-9681.

Nasrollahi, S. M., M. Imani, and Q. Zebeli. 2016. A meta-analysis and meta-regression of the impact of particle size, level, source and preservation method of forages on chewing behavior and ruminal fermentation in dairy cows. Anim. Feed Sci. Technol. 219:144-158. https://doi.org/10.1016/j.anifeedsci.2016.06.012.

Oba, M., and M. S. Allen. 1999. Evaluation of the importance of the digestibility of neutral detergent fiber from forage: Effects on dry matter intake and milk yield of dairy cows. J. Dairy Sci. 82:589596. https://doi.org/10.3168/jds.S0022-0302(99)75271-9.

Poppi, D. P., W. C. Ellis, J. H. Matis, and C. E. Lascano. 2001. Marker concentration patterns of labelled leaf and stem particles in the rumen of cattle grazing bermuda grass (Cynodon dactylon) analysed by reference to a raft model. Br. J. Nutr. 85:553-563. https://doi.org/10.1079/BJN2001317.

Schröder, U. J., and R. Staufenbiel. 2006. Invited review: Methods to determine body fat reserves in the dairy cow with special regard to ultrasonographic measurement of backfat thickness. J. Dairy Sci. 89:1-14. https://doi.org/10.3168/jds.S0022-0302(06)72064-1.

Susenbeth, A., T. Dickel, K. H. Südekum, W. Drochner, and H. Steingaß. 2004. Energy requirements of cattle for standing and for ingestion, estimated by a ruminal emptying technique. J. Anim. Sci. 82:129-136

Susenbeth, A., R. Mayer, B. Koehler, and O. Neumann. 1998. Energy requirement for eating in cattle. J. Anim. Sci. 76:2701-2705. https: //doi.org/10.2527/1998.76102701x.

Tafaj, M., B. Junck, A. Maulbetsch, H. Steingass, H. P. Piepho, and W. Drochner. 2004. Digesta characteristics of dorsal, middle and ventral rumen of cows fed with different hay qualities and concentrate levels. Arch. Anim. Nutr. 58:325-342. https://doi.org/10 $.1080 / 00039420412331273259$.

Tafaj, M., Q. Zebeli, C. Baes, H. Steingass, and W. Drochner. 2007. A meta-analysis examining effects of particle size of total mixed rations on intake, rumen digestion and milk production in highyielding dairy cows in early lactation. Anim. Feed Sci. Technol. 138:137-161. https://doi.org/10.1016/j.anifeedsci.2007.06.020.

Thomas, S., and J. B. Russell. 2004. The effect of cellobiose, glucose, and cellulose on the survival of Fibrobacter succinogenes A3C cultures grown under ammonia limitation. Curr. Microbiol. 48:219223. https://doi.org/10.1007/s00284-003-4151-0.

van Knegsel, A. T. M., H. van den Brand, J. Dijkstra, W. M. van Straalen, M. J. W. Heetkamp, S. Tamminga, and B. Kemp. 2007. Dietary energy source in dairy cows in early lactation: Energy partitioning and milk composition. J. Dairy Sci. 90:1467-1476. https: //doi.org/10.3168/jds.S0022-0302(07)71632-6.

VDLUFA (Association of German Agricultural Analytic and Research Institutes). 1993. Die chemische Untersuchung von Futtermitteln. 3rd ed. VDLUFA, ed. VDLUFA-Verlag, Darmstadt, Germany.

White, R. R., M. B. Hall, J. L. Firkins, and P. J. Kononoff. 2017. Physically adjusted neutral detergent fiber system for lactating dairy cow rations. I: Deriving equations that identify factors that influence effectiveness of fiber. J. Dairy Sci. 100:9551-9568. https: //doi.org/10.3168/jds.2017-12765.

Wilkinson, J. M. 2011. Re-defining efficiency of feed use by livestock. Animal 5:1014-1022. https://doi.org/10.1017/S175173111100005X.

Zebeli, Q., J. R. Aschenbach, M. Tafaj, J. Boguhn, B. N. Ametaj, and W. Drochner. 2012. Invited review: Role of physically effective fiber and estimation of dietary fiber adequacy in high-producing dairy cattle. J. Dairy Sci. 95:1041-1056. https://doi.org/10.3168/ jds.2011-4421.

Zebeli, Q., M. Tafaj, B. Junck, V. Ölschläger, B. N. Ametaj, and W. Drochner. 2008. Evaluation of the response of ruminal fermentation and activities of nonstarch polysaccharide-degrading enzymes to particle length of corn silage in dairy cows. J. Dairy Sci. 91:2388-2398. https://doi.org/10.3168/jds.2007-0810.

Zebeli, Q., M. Tafaj, B. Metzler, H. Steingass, and W. Drochner. 2006. New aspects on the contribution of ruminal mat quality on digesta kinetics in reticulorumen of high-producing dairy cows. Übersicht zur Tierernährung 34:165-196.

Zebeli, Q., M. Tafaj, I. Weber, J. Dijkstra, H. Steingass, and W. Drochner. 2007. Effects of varying dietary forage particle size in two concentrate levels on chewing activity, ruminal mat characteristics, and passage in dairy cows. J. Dairy Sci. 90:1929-1942. https://doi .org/10.3168/jds.2006-354. 


\section{APPENDIX}

Table A1. Cows' predicted and actual intake (kg/d, as-fed basis, $\pm \mathrm{SD}$ ) of particle fractions ${ }^{1}$ when feeding diets with different forage particle size

\begin{tabular}{lrr}
\hline & \multicolumn{2}{c}{ Diet $^{2}$} \\
\cline { 2 - 3 } Items & \multicolumn{2}{c}{ CON } \\
\hline Predicted intake & \multicolumn{1}{c}{ RED } \\
$\quad$ Long & $39.8 \pm 5.24$ & $15.4 \pm 3.51$ \\
Medium & $2.0 \pm 0.58$ & $12.0 \pm 1.73$ \\
Short & $5.1 \pm 1.27$ & $20.4 \pm 2.57$ \\
Fine & $1.8 \pm 0.38$ & $4.8 \pm 0.80$ \\
Actual intake & & \\
Long & $40.3 \pm 5.25$ & $15.4 \pm 3.53$ \\
Medium & $1.9 \pm 0.66$ & $11.8 \pm 1.76$ \\
Short & $4.7 \pm 1.48$ & $20.4 \pm 2.60$ \\
Fine & $1.7 \pm 0.44$ & $5.0 \pm 0.83$ \\
\hline
\end{tabular}

${ }^{1}$ Particle fractions determined by Penn State Particle Separator with a 19-mm screen (long), 8-mm screen (medium), 1.18-mm screen (short), and a pan (fine) according to Kononoff et al. (2003a).

${ }^{2} \mathrm{CON}=$ conventional forage particle size, geometric mean $=52 \mathrm{~mm}$; $\mathrm{RED}=$ reduced forage particle size, geometric mean $=7 \mathrm{~mm}$.

${ }^{3}$ Calculated according to Leonardi and Armentano (2003). 